\title{
Pengaruh Inflasi dan Suku Bunga Terhadap Harga Saham Pada Perusahaan Perbankan Yang Terdaftar Di LQ45 Bursa Efek Indonesia
}

\author{
Yuni Rachmawati \\ Akutansi, FE Universitas Tridinanti Palembang \\ email: yunirachmawatise@gmail.com
}

\begin{abstract}
The research objective is to find out: (1) Influence of Inflation on Stock Prices in Banking companies listed on the Indonesia Stock Exchange LQ45 in 2015-2017. (2) Effect of Interest Rates on Stock Prices in Banking companies registered in the Indonesian Stock Exchange LQ45 in 2015-2017. (3) Influence of Inflation and Interest Rates on Stock Prices in Banking companies listed on the Indonesia Stock Exchange LQ45 in 2015-2017. Quantitative type, this study sample is a Banking company registered in the Indonesia Stock Exchange LQ45 in 2015-2017. The sample selection uses a saturated sampling method, with 6 (six) companies. Data analysis techniques used simple linear regression analysis and multiple regression analysis. The results of statistical analysis can be concluded that (1) Inflation has a negative and significant effect on stocks in banking companies listed on the Indonesia Stock Exchange LQ45. (2). Interest books have a negative and significant effect on stocks in banking companies listed on the Indonesian Stock Exchange LQ45. (3) Inflation and Interest Rates have a negative and significant effect on stock prices in Banking companies listed on the Indonesia Stock Exchange LQ45 in 2015-2017.
\end{abstract}

Keywords: Inflation, Interest Rates and Stock Prices

\begin{abstract}
ABSTRAK
Tujuan penelitian untuk mengetahui: (1) Pengaruh Inflasi terhadap Harga Saham pada perusahaan Perbankan yang terdaftar di LQ45 Bursa Efek Indonesia tahun 2015-2017. (2) Pengaruh Suku Bunga terhadap Harga Saham pada perusahaan Perbankan yang terdaftar di LQ45 Bursa Efek Indonesia tahun 2015-2017. (3) Pengaruh Inflasi dan Suku Bunga terhadap Harga Saham pada perusahaan Perbankan yang terdaftar di LQ45 Bursa Efek Indonesia tahun 2015-2017. Jenis kuantitatif , sampel penelitian ini adalah perusahaan Perbankan yang terdaftar di LQ45 Bursa Efek Indonesia tahun 20152017. Pemilihan sampel menggunakan metode sampling jenuh, dengan jumlah 6 (enam) perusahaan. Teknik analisis data menggunakan analisis regresi linear sederhana dan analisis regresi berganda. Hasil analisis statistik dapat disimpulkan bahwa (1) Inflasi berpengaruh negatif dan signifikan terhadap haga saham pada perusahaan Perbankan yang terdaftar di LQ45 Bursa Efek Indonesia. (2) Suku Bunga berpengaruh negatif dan signifikan terhadap haga saham pada perusahaan Perbankan yang terdaftar di LQ45 Bursa Efek Indonesia. (3) Inflasi dan Suku Bunga berpengaruh negatif dan signifikan terhadap haga saham pada perusahaan Perbankan yang terdaftar di LQ45 Bursa Efek Indonesia tahun 2015-2017.
\end{abstract}

Kata kunci: Inflasi, Suku Bunga dan Harga Saham

\section{A. Pendahuluan}

Pasar modal (capital Market) merupakan pasar untuk berbagi intrumen keuangan jangka panjang yang bisa diperjualbelikan, baik dalam bentuk utang (obligasi) maupun pasar modal sendiri (saham). Menurut Keputusan Menteri Keuangan RI No. 1548/KMK/1990, pasar modal adalah suatu sistem keuangan yang terorganisasi, termasuk di dalamnya adalah bank-bank komersial dan semua lembaga perantara di bidang keuangan, serta keseluruhan surat-surat berharga yang beredar. Pasar modal mempunyai peranan penting dalam perekonomian sebagai 
faktor pembiayaan dan alternatif sumber daya operasional bagi perusahaanperusahaan yang ada disuatu negara. Dipertegas Aziz, dkk (2015:15) pasar modal merupakan pasar untuk berbagai instrumen keuangan jangka panjang yang bisa diperjualbelikan baik surat utang (obligasi), ekuiti (saham), reksadana, instrumen derivatif maupun istrumen lainnya.

Perkembangan pasar modal merupakan salah satu indikator yang terus dipantau. Hal yang dipantau dari pasar modal antara lain adalah nilai transaksi dan volume transaksi, kapitalisasi pasar, jumlah emiten, serta indeks harga saham gabungan (IHSG). Pergerakan saham bank yang sudah go public diperkirakan dapat mempengaruhi kestabilan sistem keuangan. Jika terjadi ekspektasi positif, minat untuk membeli akan meningkat yang akan menggerakkan harga ke atas. Sebaliknya, ekspektasi negatif akan mendorong harga menurun karena tekanan jual akan meningkat. Dengan memperhatikan karakter pasar modal tersebut pergerakan saham perbankan yang sudah go public diharapkan dapat digunakan sebagai salah satu prompt indicator untuk memantau kestabilan sistem keuangan.

Pada krisis ekonomi yang pernah melanda di seluruh Asia, khususnya sektor keuangan perbankan sangat mempengaruhi kegiatan perusahaan juga perekonomian secara menyeluruh. Kegiatan bank sangat tergantung kepada kepercayaan nasabahnya pemilik dana atau saham. Aziz, (2015) menyatakan saham adalah tanda penyertaan atau kepeemilikan investor individul atau investor institusional atau trader atas investasi mereka atau sejumlah dana yang diinvestasikan dalam suatu perusahaan.

Harga saham dipengaruhi banyak faktor, jika di sektor perbankan dipengaruhi inflasi dan suku bunga sedangkan di sektor perusahaan go publik dapat dipengaruhi antara lain dapat dipengaruhi oleh Divident per Share (DPS) dan Earning per Share (EPS). Penelitian Lilianti (2018) menunjukkan hasil DPS dan EPS berpengaruh positif terhadap harga saham perusahaan sub sektor Farmasi di BEI. Selanjutnyua Darmadji dan Fakhrudin (2012:102) menyatakan harga saham adalah harga yang terjadi di bursa pada waktu tertentu. Harga saham bisa berubah naik atau pun turun dalam hitungan menit bahkan dapat berubah dalam hitungan detik. Hal tersebut dimungkinkan karena tergantung dengan permintaan dan penawaran antara pembeli saham dengan penjual saham. Harga saham merupakan salah satu indikator pengelola perusahaan. Keberhasilan dalam menghasilkan keuntungan akan memberikan kepuasan bagi investor yang rasional.

Bursa Efek Indonesia memilki 7 indeks harga saham yang secara terus menerus disebarluaskan melalui media cetak maupun elektronik, sebagai salah satu pedoman bagi investor untuk berinvestasi di pasar modal.

a. Indeks Individual, menggunakan indeks harga masing-masing saham terhadap harga dasarnya, atau indeks masing-masing saham yang tercatat di BEI.

b. Indeks Harga Saham Sektoral, menggunakan semua saham yang termasuk dalam masing-masing sektor, misalnya sektor keuangan, pertambangan, dan lain-lain. Di BEl indeks sektoral terbagi atas sembilan sektor yaitu: pertanian, pertambangan, industri dasar, aneka industri, konsumsi, properti, infrastruktur, keuangan, perdagangan dan jasa, dan manufaktur.

c. Indeks Harga Saham Gabungan atau IHSG (composite stock price index), menggunakan semua saham yang tercatat sebagai komponen penghitungan indeks. 
d. Indeks LQ 45, yaitu indeks yang terdiri 45 saham pilihan dengan mengacu kepada 2 variabel yaitu likuiditas perdagangan dan kapitalisasi pasar. Setiap 6 bulan terdapat saham-saham baru yang masuk kedalam LQ 45 tersebut.

e. Indeks Syariah atau JII (Jakarta Islamic Index). JII merupakan indeks yang terdiri 30 saham mengakomodasi syariat investasi dalam Islam atau Indeks yang berdasarkan syariah Islam. Dengan kata lain, dalam Indeks ini dimasukkan saham-saham yang memenuhi kriteria investasi dalam syariat Islam.

f. Indeks Papan Utama dan Papan Pengembangan. Indeks harga saham yang secara khusus didasarkan pada kelompok saham yang tercatat di BEI yaitu kelompok Papan Utama dan Papan Pengembangan.

g. Indeks Kompas 100, merupakan suatu indeks saham dari 100 saham perusahaan publik yang diperdagangkan di Bursa Efek Indonesia. Indeks ini merupakan bentuk kerjasama antara BEI dengan media cetak dalam hal ini kompas, dan diterbitkan pada tanggal 10 Agustus 2007. Seratus saham yang terpilih adalah saham yang memiliki tingkat likuiditas yang tinggi, nilai kapitalisasi pasar yang besar, memiliki fundamental serta kinerja yang baik.

Indeks LQ45 terdiri dari 45 saham dengan likuiditas yang tinggi, yang diseleksi berdasarkan kriteria tertentu. Kriteria pemilihan saham indeks LQ45 adalah:

a. masuk dalam urutan 60 terbesar dari total transaksi saham di pasar reguler (rata-rata nilai transaksi selama 12 bulan terakhir)

b. urutan berdasarkan kapitalisasi pasar (rata-rata nilai kapitalisasi pasar selama 12 bulan terakhir)

c. telah tercatat di BEJ selama paling sedikit 3 bulan

d. keadaan keuangan perusahaan dan prospek pertumbuhannya, frekuensi dan jumlah hari perdagangan transaksi pasar reguler.

Saham-saham yang termasuk dalam perhitungan indeks LQ45 secara rutin dipantau perkembangan kinerjanya. Setiap tiga bulan sekali dilakukan evaluasi atas pergerakan urutan saham-saham yang digunakan dalam perhitungan indeks, sementara pergantian saham yang tidak memenuhi kriteria akan dilakukan setiap enam bulan sekali yaitu pada awal bulan Februari dan Agustus. Indeks LQ45 dihitung dengan menggunakan tanggal 13 Juli 1994 sebagai hari dasar. Untuk seleksi awal digunakan data pasar dari Juli 1993-Juni 1994, dimana terpilih 45 emiten yang meliputi $72 \%$ dari total kapitalisasi pasar dan $72,5 \%$ dari total nilai transaksi di pasar reguler.

LQ45 di pasar modal sering dijadikan investor untuk berinvestasi di pasar modal karena menggambarkan dan mewakili pasar saham di Indonesia. Indeks harga saham LQ45 terus berfluktuasi yang mengakibatkan banyak perusahaan yang keluar masuk secara bergantian yang dikarenakan tinggi tingkat liquiditas, kapitalitas pasar, dan saham perusahaan yang berfluktualitas. Indeks LQ45 sebagai pelengkap IHSG, khususnya menyediakan sarana obyektif dan terpercaya bagi analisis keuangan, manajer investasi, investor dan pemerhati pasar modal lainnya dalam memonitori pergerakan harga dari saham-saham yang aktif diperdangkan. Indeks LQ45 terdiri dari saham-saham dengan likuiditas dan kapitalisasi pasar yang tinggi. Adapun faktor makro ekonomi di Indonesia yang dapat mempengaruhi harga saham LQ45 pada sektor keuangan perbankan seperti tingkat inflasi dan suku bunga. 
Sektor perbankan tidak lepas dari fluktuatif suku bunga dan inflasi adalah salah satu yang menarik perhatian untuk menginvestasikan kelebihan dananya agar mendapatkan keuntungan dengan menabung atau membeli saham yang ditawarkan oleh bank-bank tersebut. Bank dikenal sebagai tempat untuk menukar uang, memindahkan uang atau menerima segala macam bentuk pembayaran dan setoran seperti pembayaran listrik, telepon, air, pajak, uang kuliah, dan pembayaran lainnya (Kasmir, 2014).

Definisi Bank menurut Undang-Undang RI Nomor 10 Tahun 1998 adalah badan usaha yang menghimpun dana dari masyarakat dalam bentuk simpanan dan menyalurkannya kepada masyarakat dalam bentuk kredit dan atau bentuk-bentuk lainnya dalam rangka meningkatkan taraf hidup rakyat banyak. Berdasarkan pengertian di atas dapat disimpulkan bahwa bank adalah usaha yang berbentuk lembaga keuangan yang menghimpun dana dari masyarakat yang memiliki kelebihan dana (surplus of fund) dan menyalurkannya kembali kepada masyarakat yang kekurangan dana (lack of fund), serta memberikan jasa-jasa bank lainnya untuk motif profit juga sosial demi meningkatkan taraf hidup rakyat banyak.

Inflasi merupakan indikator ekonomi yang menyebabkan kenaikan harga barang dan jasa dalam suatu periode. Adanya inflasi yang tinggi akan menyebabkan naiknya biaya produksi. Brigham dan Houston (2010:228) mengemukakan inflasi (inflation) merupakan jumlah kenaikan harga dari waktu ke waktu, sedangkan tingkat inflasi adalah persentase dari kenaikan harga tersebut. Penetapan tingkat Inflasi dilakukan oleh Bank Indonesia sesuai dengan UU nomor 23 tahun 1999 tentang Bank Indonesia.

Menurut BI seperti yang dikutip dalam situs BI menyatakan bahwa indikator yang sering digunakan untuk mengukur tingkat inflasi adalah Indeks Harga Konsumen (IHK). Perubahan IHK dari waktu ke waktu menunjukkan pergerakan harga dari paket barang dan jasa yang dikonsumsi masyarakat. Sejak Juli 2008, paket barang dan jasa dalam keranjang IHK telah dilakukan atas dasar Survei Biaya Hidup (SBH) Tahun 2007 yang dilaksanakan oleh Badan Pusat Statistik (BPS). Kemudian, BPS akan memonitor perkembangan harga dari barang dan jasa tersebut secara bulanan di beberapa kota, di pasar tradisional dan modern terhadap beberapa jenis barang/jasa di setiap kota.

\begin{tabular}{|c|}
\multicolumn{2}{c}{ Tabel 1 } \\
Perkembangan Tingkat Inflasi \\
Berdasarkan Indeks Harga Konsumen (IHK)
\end{tabular}

Berdasarkan Tabel 1 diperoleh data bahwa perkembangan inflasi di tahun 2015 sebesar 3,35\% yang disebabkan oleh harga bahan bakar minyak (BBM) yang fluktuatif. Inflasi terendah pada tahun 2016 sebesar 3,02\%, tekanan inflasi tersebut terjadi pada kelompok bahan makanan yang diakibatkan oleh naik turun bahan makanan. Penurunan tekanan inflasi tersebut ditunjukkan dari kenaikan harga beberapa indeks kelompok pengeluaran kelompok bahan makanan. Pada tahun 2017 tekanan inflasi menjadi 3,16\% dengan angka tersebut inflasi masih dikatakan 
masih menurun, yang disebabkan oleh menurunnya volatile foods serta administered prices. Tidak stabilnya tingkat inflasi akan membuat investor menghadapi risiko yang tinggi untuk berinvestasi dalam bentuk saham di bursa efek mengalami penurunan, penurunan volume perdangangan di bursa efek yang berdampak pada turunnya nilai saham LQ45.

Indikator inflasi lainnya berdasarkan international best practice antara lain:

a. Indeks Harga Perdagangan Besar (IHPB). Harga Perdagangan Besar dari suatu komoditas ialah harga transaksi yang terjadi antara penjual/pedagang besar pertama dengan pembeli/pedagang besar berikutnya dalam jumlah besar pada pasar pertama atas suatu komoditas

b. Deflator Produk Domestik Bruto (PDB) menggambarkan pengukuran level harga barang akhir (final goods) dan jasa yang diproduksi di dalam suatu ekonomi (negeri). Deflator PDB dihasilkan dengan membagi PDB atas dasar harga nominal dengan PDB atas dasar harga konstan.

Berdasarkan PMK No.93/PMK.011/2014 tentang sasaran inflasi tahun 2016, 2017, dan 2018 tanggal 21 Mei 2014 sasaran inflasi yang ditetapkan oleh Pemerintah untuk periode 2016 - 2018, masing-masing sebesar 4\%, 4\% dan 3,5\% masing-masing dengan deviasi $\pm 1 \%$. Sasaran inflasi tersebut diharapkan dapat menjadi acuan bagi pelaku usaha dan masyarakat dalam melakukan kegiatan ekonominya ke depan sehingga tingkat inflasi dapat diturunkan pada tingkat yang rendah dan stabil.

Selain inflasi, suku bunga juga termasuk dalam faktor yang harus diperhatikan oleh investor. Sunariyah (2013:80) menyatakan suku bunga adalah harga dari pinjaman. Suku bunga dinyatakan sebagai persentase uang pokok per unit waktu. Bunga merupakan suatu ukuran harga sumber daya yang digunakan oleh debitur yang harus dibayarkan kepada kreditur.

Tingkat suku bunga dinyatakan Boediono (2014:76) sebagai harga dari penggunaan dana investasi (loanable funds). Tingkat suku bunga merupakan salah satu indikator dalam menentukan apakah seseorang akan melakukan investasi atau menabung. Suku bunga adalah harga yang harus dibayarkan apabila terjadi pertukaran antara satu rupiah sekarang dengan satu rupiah nanti. Tingkat bunga yang tinggi akan mendorong para pemilik modal untuk menenamkan modalnya di bank dengan alasan tingkat keuntungan yang diharapkan. Jika suku bunga deposito terus meningkat, maka adanya kecenderungan para pemlik modal mengalihkan dananya ke deposito dibandingkan dengan menanamkan modalnya di pasar modal dengan alasan tingkat keuntungan dan faktor risiko yang rendah. Hal ini berdampak negatif terhadap harga saham dimana harga saham di pasar modal akan mengalami penurunan secara signifikan. Dengan alasan tingkat keuntungan yang diharapkan atas saham lebih kecil dibandingkan dengan keuntungan dari tingkat suku bunga sehingga mengakibatkan penurunan permintaan terhadap harga saham dan harga saham akan mengalami penurunan seiring dengan kenaikan suku bunga SBI. Bank Indonesia memiliki kebijakan dalam menentukan suku bunga yang disebut dengan BI Rate.

Tingkat suku bunga sektor keuangan yang lazim digunakan sebagai panduan investor disebut juga tingkat suku bunga bebas resiko (risk free), yaitu meliputi tingkat suku bunga bank sentral dan tingkat suku bunga deposito. Di Indonesia tingkat suku bunga Bank sentral di proxykan pada tingkat suku bunga Sertifikat Bank Indonesia atau SBI (Husnan, 2003:21). Penetapan tingkat bunga dilakukan oleh 
Bank Indonesia sesuai dengan UU nomor 23 tahun 1999 tentang Bank Indonesia. BI Rate adalah Suku bunga dengan tenor 1 bulan yang diumumkan oleh Bank Indonesia secara periodik untuk jangka waktu tertentu yang berfungsi sebagai sinyal atau stance kebijakan moneter.

Tabel 2

Perkembangan Tingkat Suku Bunga atau BI Rate

\begin{tabular}{|c|c|}
\hline Tahun & BI Rate \\
\hline 2015 & $7.50 \%$ \\
\hline 2016 & $4.75 \%$ \\
\hline 2017 & $4.25 \%$ \\
\hline
\end{tabular}

Sumber : Bank Indonesia, 2018

Berdasarkan Tabel 2 tingkat suku bunga selama periode 2015-2017 diketahui bahwa tingkat suku bunga tertinggi sebesar $7,50 \%$ terjadi pada tahun 2015 . Pada tahun 2016 dan 2017 suku bunga menurun 4,75\% dan 4,25\%, penurunan ini disebabkan oleh faktor dalam perekonomian. Tidak stabilnya suku bunga mengakibatkan investor lebih tertarik berinvestasi di bank yang memiliki risiko yang lebih rendah dibandingkan berinvestasi di saham. Berkurangnya ketertarikan investor berinvestasi dalam bentuk saham akan mengakibatkan volume transaksi saham di Bursa Efek Indonesia berkurang dan menyebabkan nilai dari saham LQ45 melemah. Dengan demikian suku bunga dan keuntungan merupakan variabel penting yang sangat berpengaruh terhadap keputusan para investor, di mana berdampak terhadap keinginan investor untuk melalukan investasi portofolio di pasar modal dengan suku bunga yang rendah.

Reseach gap penelitian ini ingin membuktikan hasil penelitian Wulandari (2016) yang menyatakan bahwa secara simultan dan parsial inflasi dan suku bunga berpengaruh positip terhadap harga saham. Secara parsial inflasi berpengaruh positif terhadap harga saham dan suku bunga berpengaruh negatif terhadap harga saham. Ginting dkk (2016) menyatakan suku dan inflasi secara parsial tidak berpengaruh terhadap harga saham.

\section{B. Rumusan Masalah}

Rumusan masalah dalam penelitian ini adalah bagaimana pengaruh Inflasi dan suku bunga secara simultan dan parsial terhadap harga saham pada perusahaan perbankan yang terdaftar di LQ45 Bursa Efek Indonesia?

\section{Populasi dan Sampel}

Sugiono (2017:80), menyatakan populasi adalah wilayah generalisasi yang terdiri atas objek/subjek yang mempunyai kualitas dan karakteristik tertentu yang ditetapkan oleh peneliti untuk mempelajari dan kemudian di tarik kesimpulannya. Populasi dalam penelitian ini adalah enam perusahaan Sektor Perbankan yang terdaftar di LQ45 Bursa Efek Indonesia (BEI) tahun pengamatan 2015-2017: 
Tabel 4.

Populasi Penelitian

\begin{tabular}{|c|l|l|c|}
\hline No. & $\begin{array}{c}\text { Kode } \\
\text { Emiten }\end{array}$ & \multicolumn{1}{|c|}{ Nama Perusahaan } & Tanggal IPO \\
\hline 1. & BBCA & Bank Central Asia Tbk & 31 Mei 2000 \\
\hline 2. & BBNI & Bank Negara Indonesia (Persero) Tbk & 25 Nov 1996 \\
\hline 3. & BBRI & Bank Rakyat Indonesia (Persero) Tbk & 10 Nov 2003 \\
\hline 4. & BBTN & Bank Tabungan Negara (persero) Tbk & 17 Des 2009 \\
\hline 5. & BJBR & $\begin{array}{l}\text { Bank Pembangunan Daerah Jawa } \\
\text { Barat dan Banten Tbk }\end{array}$ & 08 Jul 2010 \\
\hline 6. & BMRI & Bank Mandiri (Persero) Tbk & 14 Jul 2003 \\
\hline \multicolumn{2}{|c|}{ Sumber : www.idx.co.id }
\end{tabular}

Sampel adalah bagian dari jumlah dan karakteristik yang dimiliki oleh populasi tersebut. Teknik penarikan sampel dengan sampling jenuh/sensus yaitu teknik penentuan sampel bila semua anggota populasi digunakan sebagai sampel. Hal ini seiring dilakukan bila jumlah populasi relatif kecil, kurang dari 30 orang, atau penelitian yang ingin membuat generalisasi dengan kesalahan yang sangat kecil.

Tabel 5

Kriteria Pengambilan Sampel Penelitian

\begin{tabular}{|l|c|c|}
\hline \multicolumn{1}{|c|}{ Kriteria } & $\begin{array}{c}\text { Jumlah } \\
\text { perusahaan }\end{array}$ & $\begin{array}{c}\text { Kriteria } \\
\text { Sampel }\end{array}$ \\
\hline $\begin{array}{l}\text { Perusahaan yang bergerak di } \\
\text { sektor perbankan yang terdaftar } \\
\text { di LQ45 BEl periode 2015-2017. }\end{array}$ & $\mathbf{6}$ & $\mathbf{5 4}$ \\
\hline $\begin{array}{l}\text { Perusahaan yang mengalami } \\
\text { suspensi, delisting maupun go } \\
\text { private pada periode 2014-2016. }\end{array}$ & $\mathbf{0}$ & $\mathbf{0}$ \\
\hline $\begin{array}{l}\text { Perusahaan yang tidak di audit } \\
\text { pada periode 2014-2016 }\end{array}$ & $\mathbf{0}$ & $\mathbf{0}$ \\
\hline Jumlah Sampel Penelitian & $\mathbf{6}$ & $\mathbf{5 4}$ \\
\hline
\end{tabular}

Sumber : www.idx.co.id, diolah

Kerangka pemikiran dalam penelitian ini menggambarkan hubungan dan pengaruh kausal variabel inflasi dan suku bunga terhadap harga saham. Dengan hipotesis berbunyi:

$\mathrm{H} 1$ : Inflasi berpengaruh positif terhadap harga saham

H2: Suku bunga berpengaruh positif terhadap harga saham

H3: Inflasi dan Suku bunga berpengaruh positif terhadap harga saham 


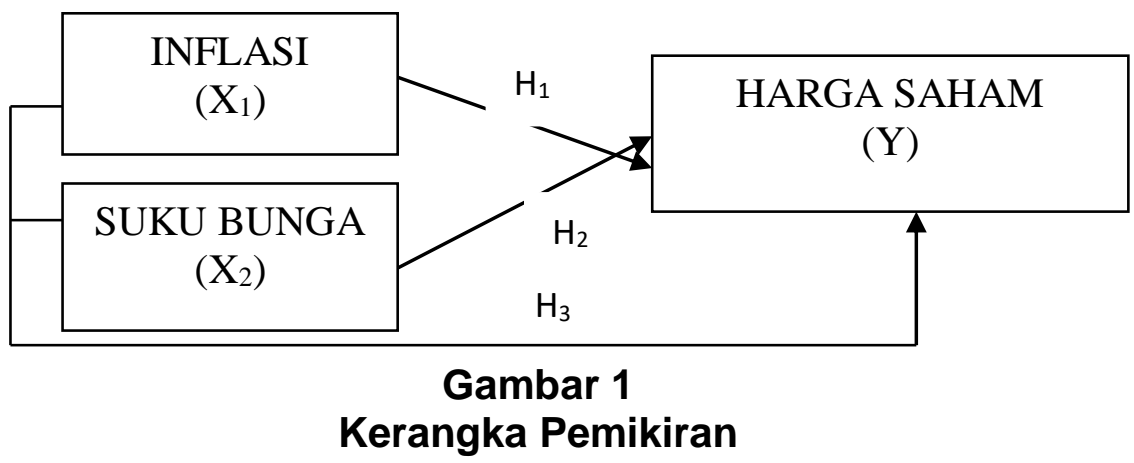

Sebelum melakukan pengujian hipotesis, terlebih dahulu dilakukan uji asumsi klasik. Suatu model penelitian dikatakan cukup baik dan dapat digunakan untuk mempredeksi jika lolos serangkaian uji asumsi klasik yang melandasinya. Uji asumsi klasik yang akan dilakukan terdiri dari: uji normalitas, uji multikolinieritas, uji autokolerasi, dan uji heteroskedastisitas. Model analisis dengan analisis regresi linier berganda. Sugiyono (2014: 270) menyatakan bahwa regresi linier berganda didasarkan pada hubungan fungsional ataupun kausal lebih dari satu variabel independen dengan satu variabel dependen.

$$
Y=a+b^{1} X^{1}+b^{2} X^{2}+e
$$

Keterangan :

$$
\begin{array}{ll}
\mathrm{Y} & =\text { Harga Saham } \\
\mathrm{a} & =\text { Konstanta } \\
\mathrm{b}_{1}, \mathrm{~b}_{2} & =\text { Koefisien Regresi } \\
\mathrm{X}_{1} & =\text { Inflasi } \\
\mathrm{X}_{2} & =\text { Suku Bunga } \\
e & =\text { error term }
\end{array}
$$

\section{Uji Hipotesis}

\section{Uji F (pengujian secara simultan)}

Untuk mengetahui pengaruh variabel independen (Inflasi dan Suku Bunga) terhadap variabel dependen (Harga saham) secara simultan digunakan uji F.

\section{Uji t (pengujian secara parsial)}

Uji-t digunakan untuk mengetahui variabel independen secara individual/parsial berpengaruh secara signifikan terhadap variabel dependen. Perhitungan dapat dengan probabilitas dari t hitung dengan signifikan alpha 0.05. bila sig $\mathrm{t}<\mathrm{Sig} \alpha=0.05$, maka terima $\mathrm{H} 0$ dan $\mathrm{H} 1$ dan berlaku sebaliknya.

\section{Hasil dan Pembahasan}

\section{Hasil Uji Normalitas}

Uji normalitas dilakukan untuk menguji data varaibel bebas dan data variabel terikat pada persamaan regresi yang dihasilkan, apakah berdistribusi tidak normal. Uji statistik yang digunakan adalah uji statistik non-parametrik Kolmogorov-Smirnov test. 
Tabel 6

Hail Uji Normalitas

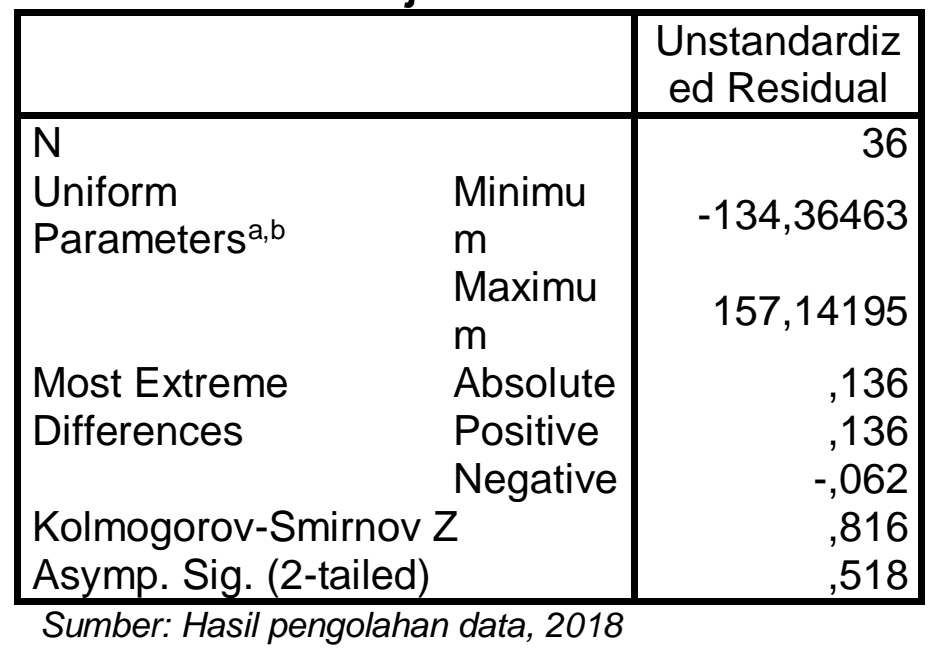

Hasil analisis residual pada Tabel 6menyatakan bahwa nilai signifikan dari fungsi regresi variabel inflasi, suku bunga dan harga saham adalah sebesar 0,518. Nilai tersebut lebih besar dari 0,05. Hal ini dapat disimpulkan bahwa fungsi regresi dari ketiga variabel tersebut telah berdistribusi normal.

\section{Hasil Uji Multikolineritas}

Uji multikolinieritas untuk mengetahui ada atau tidaknya gejala hubungan dengan melihat nilai Tolerance dan VIF (Variance Inflation Factor).

\begin{tabular}{|c|c|c|}
\hline \multirow[b]{2}{*}{ Variabel } & \multicolumn{2}{|c|}{$\begin{array}{l}\text { Collinearity } \\
\text { Statistics }\end{array}$} \\
\hline & Tolerance & VIF \\
\hline \multirow{2}{*}{$\begin{array}{ll}1 & \text { (Constant) } \\
& \text { Inflasi }\end{array}$} & & \\
\hline & 361 & 2,77 \\
\hline Suku Bunga & ,361 & $\begin{array}{r}2,77 \\
0\end{array}$ \\
\hline
\end{tabular}

Tabel 7 menyatakan angka Tolerance variabel inflasi sebesar 0,361 dan variabel suku bunga sebesar 0,361. Variabel independen memiliki nilai Tolerance > 0,10 . Sedangkan nilai VIF variabel inflasi sebesar 2,770 dan variabel suku bunga sebesar 2,770. Bahwa variabel independen memiliki nilai VIF kurang dari 10. Maka, dapat disimpulkan bahwa tidak terjadi gejala multikolinieritas pada model regresi.

\section{Hasil Uji Autokorelasi}

Uji autokorelasi bertujuan untuk menguji apakah dalam model regresi ada korelasi antara kesalahan penganggu periode $\mathrm{t}$ (berada) dan kesalahan periode $\mathrm{t}-1$ (sebelumnya). Berikut hasil output uji autokorelasi menggunakan uji Durbin-Watson. 
Tabel 8

Hasil Uji Autokorelasi

\begin{tabular}{|l|c|r|r|r|r|}
\hline $\begin{array}{l}\text { Mode } \\
\mathrm{I}\end{array}$ & $\mathrm{R}$ & $\begin{array}{c}\mathrm{R} \\
\text { Square }\end{array}$ & $\begin{array}{c}\text { Adjusted R } \\
\text { Square }\end{array}$ & $\begin{array}{c}\text { Std. Error of } \\
\text { the Estimate }\end{array}$ & $\begin{array}{c}\text { Durbin- } \\
\text { Watson }\end{array}$ \\
\hline 1 &, $795^{\mathrm{a}}$ &, 631 &, 609 & 81,23519 &, 434 \\
\hline
\end{tabular}

Sumber: Data diolah Peneliti, 2018

Tabel 8 menunjukkan nilai DW sebesar 0,43. Berdasarkan kriteria bahwa pengambilan keputusan bahwa nilai DW diantara -2 sampai +2 atau $\leq \mathrm{DW} \leq+$ berarti tidak terjadi autokorelasi. Dapat disimpulkan bahwa tidak terjadi autokorelasi dalam model regresi ini.

\section{Hasil Uji Heteroskesdastisitas}

Uji heteroskesdastisitas bertujuan menguji apakah dalam model regresi terjadi ketidaksamaan varians dari residual observasi yang satu dengan observasi yang lain. Model regresi yang baik adalah yang tidak terjadi heteroskedasitas.

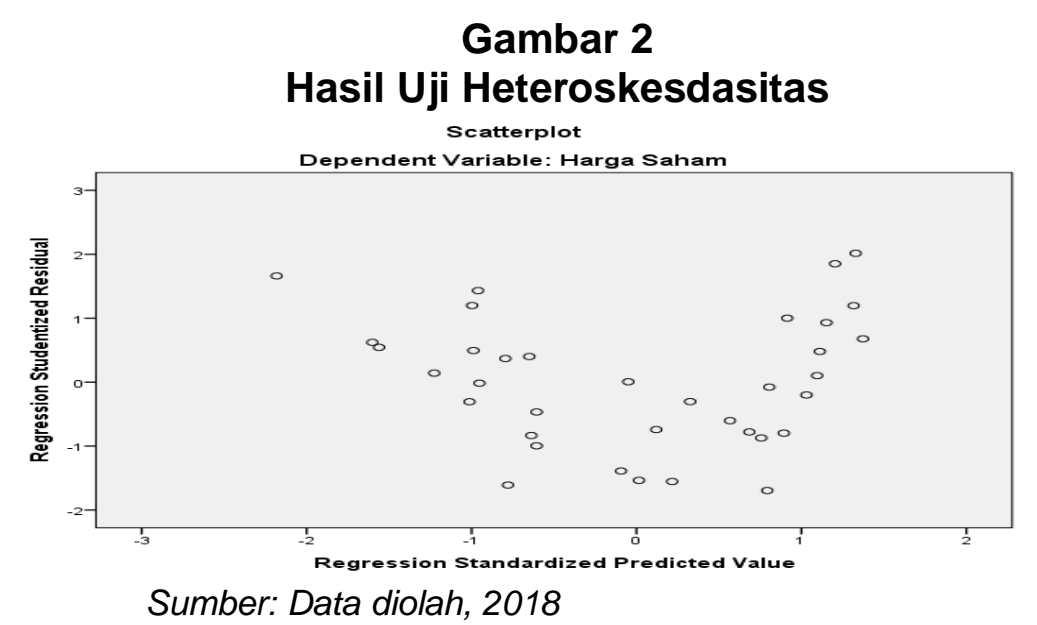

Berdasarkan gambar 4, grafik Scatterplot di atas terlihat bahwa titik-titik dari data menyebar secara acak serta tersebar baik di atas maupun di bawah angka nol dari sumbu $Y$ dan tidak membentuk suatu pola tertentu, seperti parabola. Maka dapat disimpulkan tidak terjadi heteroskedasitas dalam model regresi.

\section{Hasil Uji Analisis Regresi Linear Berganda}

Untuk mengetahui pengaruh inflasi dan suku bunga terhadap harga saham, hasl penelitiannya dapat dilihat di tabel berikut:

Tabel 9

Hasil Uji Regresi Berganda

\begin{tabular}{|c|c|c|c|}
\hline \multirow[b]{2}{*}{ Model } & \multicolumn{2}{|c|}{$\begin{array}{l}\text { Unstandardized } \\
\text { Coefficients }\end{array}$} & $\begin{array}{c}\text { Standardized } \\
\text { Coefficients }\end{array}$ \\
\hline & $\mathrm{B}$ & Std. Error & Beta \\
\hline $\begin{array}{ll}1 & \text { (Constant) } \\
\text { Inflasi }\end{array}$ & $\begin{array}{r}1244,619 \\
41,603\end{array}$ & $\begin{array}{l}62,204 \\
15,242\end{array}$ & ,480 \\
\hline $\begin{array}{l}\text { Suku } \\
\text { Bunga }\end{array}$ & $-108,163$ & 16,927 & $-1,124$ \\
\hline
\end{tabular}



berikut:

Berdasarkan hasil perhitungan regresi berganda, didapat persamaan sebagai $\mathrm{Y}=1244,619+41,603 \mathrm{X}_{1}-108,163 \mathrm{X}_{2}+e$

\section{Hasil Uji Hipotesis}

Hasil Uji F (pengujian secara simultan)

Uji F (simultan) pada dasarnya menunjukkan apakah semua variabel independen atau bebas mempunyai pengaruh secara bersama-sama terhadap vaiabel dependen atau terikat.

Tabel 10

Hasil Perhitungan Uji F (simultan)

\begin{tabular}{|l|c|r|r|r|r|}
\hline Model & $\begin{array}{c}\text { Sum of } \\
\text { Squares }\end{array}$ & Df & \multicolumn{1}{c|}{$\begin{array}{c}\text { Mean } \\
\text { Square }\end{array}$} & F & Sig. \\
\hline 1 Regressio & 372877,453 & 2 & 186438,727 & 28,252 &, $000^{\mathrm{b}}$ \\
$\mathrm{n}$ & 217772,131 & 33 & 6599,155 & & \\
$\quad$ Residual & & & \\
$\quad$ Total & 590649,584 & 35 & & & \\
\hline
\end{tabular}

\section{Uji t (pengujian secara parsial)}

Uji t secara parsial digunakan untuk mengetahui apakah secara parsial variabel independen berpengaruh secara signifikan atau tidak terhadap variabel dependen. Hubungan secara parsial ditinjau dari signifikan dan nilai t hitung.

Tabel 11

Hasil Perhitungan Uji t

\begin{tabular}{|c|c|c|}
\hline Model & $\mathrm{t}$ & Sig. \\
\hline 1 (Constant) & 20,009 &, 000 \\
\hline Inflasi & 2,730 & ,010 \\
\hline Suku Bunga & $-6,390$ &, 000 \\
\hline
\end{tabular}

Perhitungan Tabel 11 inflasi menunjukkan nilai signifikansi sebesar 0,010< sig $\alpha=0,05$ artinya terdapat pengaruh positif inflasi terhadap harga saham. Suku bunga menunjukkan nilai signifikansi sebesar $0,000<$ sig $\alpha=0,05$ artinya terdapat pengaruh positif suku bunga terhadap harga saham, maka terima $\mathrm{H}_{0}$ dan ditolak $\mathrm{H}_{1}$.

\section{Pengaruh Inflasi terhadap Harga Saham pada Perusahaan Perbankan di LQ45 Bursa Efek Indonesia}

Dari hasil uji t dapat disimpulkan bahwa tingkat inflasi merupakan berpengaruh negatif dan signifikan dalam memprediksi harga saham, secara parsial faktor inflasi mempunyai pengaruh terhadap kenaikan harga saham jadi kenaikan inflasi menyertakan harga saham suatu perusahaan ikut meningkat. Hal ini menyimpulkan bahwa kenyataan empiris menunjukkan pada beberapa emerging stock markets, inflasi berkorelasi secara negatif dengan tingkat pengembalian investasi pada 
saham. Mengindikasikan bahwa tingkat inflasi yang tinggi diharapkan tingkat pengembalian investasi pada saham tinggi.

Peningkatan harga barang dan bahan baku juga akan membuat biaya produksi tinggi, sehingga akan berpengaruh jumlah permintaan. Penurunan jumlah permintaan ini akan berdampak pada menurunnya laba perusahaan dan berpengaruh pada harga saham perusahaan. Ekspektasi laju inflasi yang tinggi akan mendorong masyarakat untuk mengalihkan aset finansial yang dimilikinya menjadi aset riil, seperti tanah, rumah, dan barang-barang konsumsi lainya. Begitu pula sebaliknya ekspektasi laju inflasi yang rendah akan memberikan insentif terhadap masyarakat untuk menabung serta melakukan investasi pada sektor sektor produktif. Inflasi merupakan suatu variabel ekonomi makro yang dapat merugikan suatu perusahaan. Inflasi yang tinggi menjadi momok bagi pelaku pasar modal karena akan meningkatkan biaya produksi, yang akan berakibat buruk terhadap harga dan pendapatan. Para pelaku pasar modal lebih memandang inflasi sebagai suatu resiko yang harus dihindari. Pemilik saham dan pelaku pasar modal akan lebih suka melepas saham yang mereka miliki ketika inflasi tinggi.

Didukung pendapat Wardani (2016) yang menyatakan kondisi fundamental, inflasi dan suku bunga berpengaruh positif terhadap harga saham.

\section{Pengaruh Suku Bunga terhadap Harga Saham pada Perusahaan Perbankan di LQ45 Bursa Efek Indonesia}

Penelitian ini mengindikasikan bahwa perubahan suku bunga akan mempengaruhi harga saham secara terbalik, ceteris paribus. Artinya jika suku bunga meningkat, maka harga saham akan turun dan sebaliknya. Harga saham yang turun ini akan menyebabkan return saham yang turun pula. Hal ini disebabkan karena dalam menghadapi kenaikan suku bunga, para pemegang saham akan menahan sahamnya sampai tingkat suku bunga kembali pada tingkat yang dianggap normal. Sebaliknya, jika tingkat suku bunga jangka panjang meningkat maka pemegang saham cenderung menjual sahamnya karena harga jualnya tinggi. Kenaikan suku bunga akan sangat berpengaruh bagi pelaku pasar modal. Kondisi ini akan menarik minat investor yang sebelumnya berinvestasi di saham untuk memindahkan dananya dari saham ke dalam deposito. Jika banyak investor yang menjual sahamnya, maka harga saham akan turun. Sehingga investor yang memilih berinvestasi di deposito karena bunga yang ditawarkan oleh bank lebih tinggi dibandingkan berinvestasi dalam bentuk saham yang berisiko.

Pergerakan suku bunga SBI yang fluktuatif dan cenderung meningkat akan mempengaruhi pergerakan sektor riil yang dicerminkan oleh pergerakan return saham. Akibat meningkatnya suku bunga, para pemilik modal akan lebih suka menanamkan uangnya di bank dari pada berinvestasi dalam bentuk saham. Sebaliknya pada saat suku bunga BI rate yang menurun, suku bunga deposito pun akan turun. Sehingga investor akan mencari alternatif yang dapat memberikan hasil investasi lebih tinggi dan menguntungkan dibandingkan deposito yaitu saham. Akibatnya terjadi permintaan yang besar pada saham yang menyebabkan harga saham naik. Naiknya harga saham yang meningkatkan pula jumlah return investor berupa capital gain yang cukup menarik bagi investor.

Hasil penelitian ini memiliki persamaan dengan penelitian sebelumnya yang menyatakan suku bunga dan inflasi secara simultan berpengaruh pada harga saham perusahaan Subsektor Perbankan (Ginting, dkk, 2016). 


\section{E. Kesimpulan}

Berdasarkan hasil analisis dan pembahasan, maka dapat disimpulkan bahwa Inflasi berpengaruh negatif dan signifikan terhadap harga saham pada perusahaan dengan taraf signifikan $5 \%$ dan nilai signifikasi $(0,011)$ lebih kecil dari taraf signifikansi $(0,05)$. Suku bunga berpengaruh negatif dan signifikan terhadap harga saham dengan taraf signifikan $5 \%$ dan nilai signifikasi $(0,000)$ lebih kecil dari taraf signifikansi $(0,05)$. Inflasi dan suku bunga secara simultan berpengaruh dan signifikan terhadap harga saham ditunjukkan dengan nilai signifikansi $(0,000)$ lebih kecil dari taraf signifikansi.

\section{F. Saran}

Saran bagi investor hendaknya mempertimbangkan setiap pergerakan inflasi dan suku bunga. Setiap pergerakan dapat menyebabkan harga saham fluktuatif dan mempengaruhi nilai perusahaan. Investor dan calon investor yang akan melakukan transaksi di pasar dapat menganalisis faktor-faktor inflasi dan suku bunga. Keterbatasan dari segi faktor makro ekonomi yang digunakan sebagai dasar untuk memprediksi harga saham perusahaan hanya terbatas pada tingkat inflasi dan suku bunga, diharapkan dalam penelitian selanjutnya untuk memperhatikan pengaruh faktor-faktor lain yang dapat mempengaruhi pergerakan harga saham perusahaan seperti produk domestik, tingkat pengangguran, harga emas, nilai kurs dollar dan lain-lain.

\section{DAFTAR PUSTAKA}

Azis, Minarti, dan Nadir. (2015). Manajemen Investasi Fundamental, Teknikal, Perilaku Investor dan Return Saham. Yogyakarta: DEEPUBLISH (Grup Penerbitan CV BUDI UTAMA).

Boediono. (2014). Ekonomi Makro. Yogyakarta: BPFE.

Brigham dan Houston. (2010). Dasar-Dasar Manajemen Keuangan. Jakarta: Salemba Empat.

Darmadji dan Fakhrudin. (2012). Pasar Modal di Indonesia Pendekatan Tanya Jawab. Jakarta: Salambe Empat.

Ginting, Marisa, Maria \&Topowijono, Sulamiyati.(2016). Pengaruh Suku Bunga dan Inflasi terhadap harga Saham (Studi pada Sub Sektor Perbankan di Bursa Efek Indonesia). Jurnal Administrasi Bisnis (JAB). Vol.35(2) Juni 2016. Hal:77-85. Diakses:Https://administrasi bisnis.Studentjournal.ub.ac.id

Husnan. (2003). Manajemen Keuangan Teori dan Penerapan (keputusan Jangka Pendek). Yogyakarta: BPFE.

Kasmir. (2014). Bank dan Lembaga Keuangan Lainnya. Jakarta: Raja Grafindo Persada.

Lilianti, Emma. (2018) Pengaruh Divident per Share (DPS) dan Earning per Share (EPS) terhadap Harga Saham pada Perusahaan Sub Sektor Farmasi di Bursa Efek Indonesia (BEI). Jurnal Ecoment Global. Vol.3(1) Februari 2018. Hal: 1222. Https://uigm.ac.id. 
Republik Indonesia. (2008). Undang-Undang RI Nomor 10, Tahun 1998. Defenisi Bank. Jakarta: Bank Indonesia.

Republik Indonesia. (2014). Undang-Undang Republik Indonesia No. 3, 2014. Tentang Bank Indonesia. Jakarta: Bank Indonesia.

Sugiyono, (2014). Metode Penelitian Kuantitatif dan $R \& D$. Bandung: Alfabeta.

Sunariyah, (2013). Pengantar Pengetahuan Pasar Modal. Penerbit: UPP STIM YKPN, Yogyakarta.

Wardani, Dewi \& Andarini, Devita (2016). Pengaruh Kondisi Fundamental, Inflasi, dan Suku Bunga Sertifikat Bank Indonesia terhadap bank Harga Saham (Study Kasus pada Perusahaan Real Estate dan Property yang Terdaftar di Bursa Efek Indonesia Tahun 2010-2013). Jurnal Akuntansi. Vol.4 (2) Desember 2016. https://Download.portalgaruda.org.article

Wulandari, Anna \& Andriani, Meli. (2016). Pengaruh Inflasi dan Suku Bunga terhadap Harga saham Perusahaan Sektor Properti dan Real Estate di Bursa Efek Indonesia. Jurnal Manajemen Kewirausahaan. Vol.13(2). Hal: 113-118. Https://ejurnal.stiepwija.ac.id.article.view. 